According to Goldsmith, who first recorded the Suffolk outbreak ${ }^{8}$, larvæ had been noted at Beccles some five years before his attention was directed to them. It is thus possible that there may have been a small nuclear colony of the species in Suffolk for many years. This, however, is not very likely, since the Beccles neighbourhood has been fairly well worked in respect of the Lepidoptera, and the 'nests' of the larvæ are so conspicuous that they could searcely be overlooked. On the whole, it is more probable that the species is a recent arrival in Suffolk, having either flown or been carried by boat from the Continent.

If this suggestion is correct, the conditions favouring an epidemic increase might easily have been fulfilled, since the moth would arrive without its natural parasites, and feedıng upon willows in a marshland district, where other members of the genus are not abundant, it would gain some years' start before being found by any indigenous parasites. In 1936, the rate of parasitism was certainly very low. Mr. Stringer, of the British Museum (Natural History), reared from Beccles larvæ the species Herp sstomus brunneicornis Grav., an ichneumonid that frequently attacks the allied Hyponomeuta padella; but the writer obtained no parasites whatever either from Beccles or from Barnby material.

Provisionally, then, $H$. rorella may be regarded as an invader (in contradistinction to the indigenous C. graminis), and although it is very unsafe to prophesy, it is at least possible that it will be increasingly parasitized, and even perhaps brought completely under control as soon as it is discovered by the parasites of our native species of Hyponomeuta-a process that might be hastened artificially if it were considered worth while.

As to the economic importance of the insect, it is not possible as yet to give any definite opinion. If ericket bat willow or basket willow were attacked, the species might prove a serious menace, notably to the former, since the spraying of large trees is seldom commercially worth while. Fortunately, there is some hope that neither will be affected. In Suffolk, the trees that are suffering appear to be Salix alba (although the writer claims no expert knowledge in this respect). However this may be, larvæ of the rorella brought from Beccles, and also others reared in captivity from the egg, have been given the foliage of the true cricket bat willow, but neither in 1936 nor 1937 were they able to survive on it. Similarly, they refused to feed on Salix caprea or other 'sallows', or on one of the basket willows that was given them. The experiments were not sufficiently extensive to justify any final conclusion in respect of the cricket bat willow, but they are at least suggestive and show that $H$. rorella is very specifiz in its tastes.

A note on the outbreak in 1936 was published in the Entomologist ${ }^{2}$, to which readers may be referred for a description of the larvæ and the damage they do.

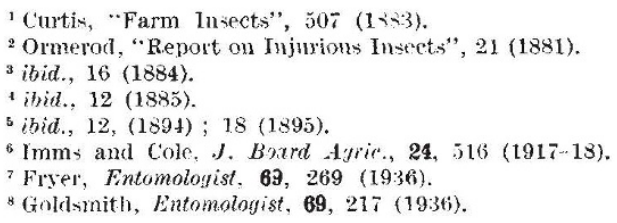

\title{
Nottingham Meeting of the British Association
}

\begin{abstract}
$\mathrm{A}^{\mathrm{s}}$ has already been announced, the annual meeting of the British Association will this year be held in Nottingham on September 1-8, under the presidency of Sir Edward Poulton. Twice previously the Association has held its annual meeting in Nottingham. In 1866, before the foundation of University College, Nottingham, Mr. Justice Grove, Q.C., the inventor of the Grove cell, was president. It was at this meeting that Wheatstone was president of Section A (Mathematics and Physies), before which Joule read a short paper on the heating effect of an electric current in a wire, and one wonders if this paper was an abridged version of that which Wheatstone is reputed to have rejected in his capacity as a referee for Royal Society publications. At the same meeting, Sir William Huggins gave an evening
\end{abstract}

discourse on the applications of spectroscopy to the problems of stellar constitution. Among the more distinguished members present in 1866 were Frank Buckland, T. H. Huxley, A. R. Wallase," W. Crookes and H. E. Roscoe, while Dean Farrar contributed to discussions on the teaching of science in publie schools, and C. F. Varley reported on the Atlantic cable successfully completed a month before the meeting. Among the visits paid to local industrial undertakings was one to Messrs. Taylor's bell foundry in Loughborough, and it is pleasant to think that members will again have an opportunity of visiting the works this September.

In 188I the University College, Nottingham, buildings in Shakespeare Street, near the centre of the city, were opened, and these were the headquarters of the Association at its annual meeting 
in 1893. Dr. J. S. Burdon Sanderson was president, and Sir Richard Glazebrook was president of Section A, which was remarkably active, and at which a committee presented a report on the foundation of a National Physical Laboratory.

This year the Association will hold all its sectional meetings in the University College buildings in University Park, provided by the munificence of the late Lord Trent and opened by H.M. King George V in July 1928. Here the members will be able to enjoy extremely pleasant surroundings, and, if they wish, refresh themselves in an openair swimming pool.

Nottingham is the centre of a large number of industries; its connexion with textiles is well known, and there are large chemical, mining, tobacco, bieycle and general engineering undertakings in the city and immediate vicinity. Since the last meeting here, interest in lace manufacture has declined, or, rather, been replaced by activity in hosiery manufacture. Visits to representative works have been arranged, including an excursion to a coal mine, and the Geography and Geology Sections of the Association are combining in a discussion on the potential resources of the area. Members visiting Nottingham for the first time will find much to interest them in the many excursions which have been arranged to the surrounding countryside.

A meeting in which local members should be considerably interested is an evening discussion arranged between six sections on the planning of the land of Britain. A joint meeting of the Education and Geology Sections to discuss the teaching of geology in schools is also likely to be keenly followed, and Mr. H. G. Wells's presidential address to the Education Section will naturally be of considerable interest. In addition to the evening discourses, one on "Illusions of Colour" to be given by Prof. H. Hartridge and another on "Grass and the National Food Supply" by Dr. R. E. Slade, a series of popular lectures for non-members has been arranged in the neighbouring towns. Dr. Alexander Wood will address a company of Nottingham children on "Noise", Sir Gilbert Walker will talk to a Derby audience on "The Science of Sports", Mr. R. Kay Gresswell will talk on "Rivers" at Lincoln, Dr. J. E. Constable on "Everyday Application of Physics.' at Long Eaton, Prof. J. Walton on "Coal and its Origin" at Mansfield and Mr. T. M. Herbert on "Transport of Food" at Newark.

The Lord Mayor and members of the City Council will hold a civic reception at Nottingham Castle on Thursday evening, September 2, and the College Council will give a garden party on September 7 . On these occasions members should find ample opportunity of meeting many of the local scientific workers and citizens who are interested in the aims and objects of the Association and who are working to make the Nottingham meeting a successful one in every way.

\section{Obituary}

Prof. Thomas Mather, F.R.S.

$\mathrm{T}$ HOMAS MATHER was a man who worked his way up to an important and honourable position from a starting condition devoid of all advantages due to financial or personal support. His early training was that of a carpenter. By strenuous evening study he won a Whitworth Scholarship at a time when these scholarships were few in number and of greater money value than is nowadays the case. With the aid of this scholarship, he supported himself at college throughout a fairly complete course of full-time study. His early education was not such as to make it possible for him to meet all the academic conditions at that time needed in order to qualify for a science degree. He could not get a degree but he could, and did, work hard at physical, mathematical, and engineering subjects, so as to leave college with a thorough grip of them. He next became an assistant to Prof. W. E. Ayrton at the start of the technical teaching work financed by the City and Guilds of London Institute. He followed Prof. Ayrton from the college at Finsbury to the one at South Kensing- ton which is now part of the Imperial College. On the death of Prof. Ayrton he succeeded him as pro. fessor of electrical engineering. When he died on June 23, he had lived more than eighty-one years, and during half that period he was a fellow of the Royal Society.

Mather joined Prof. Ayrton's staff at Finsbury in 1881 before the College was actually built, and while the City-Guilds classes were carried on in a boys' school, part of the playground of which was after. wards used as the site for the College. The classes at the school and later on at the College were held mainly in the evening, and were thronged with adult students all engaged in the new industry of electrical engineering. At that time, trained men were not to be found, and electrical engineering departments did not exist. There was a new and sudden demand for large laboratory classes to train men in the use of apparatus utilizing electrical currents of a magnitude previously unknown. The development of suitable training courses with corresponding testing appliances called for much ability and initiative. Prof. Ayrton 